\title{
Psikolojik Yıldırma ve Örgütsel Bağlılık İlişskisinde Önyargının Aracılık Rolü
}

\begin{abstract}
Ali BALTACI
$\ddot{O} z$

$\mathrm{Bu}$ çalışma örgütsel bağl1lık ve psikolojik yıldırma ilişkisinde önyargının aracılık etkisini belirlemeyi amaçlamaktadır. Psikolojik yıldırma, örgütteki bir çalışanın diğer çalışanlara uyguladığı olumsuz eylem ve davranışlardır. Örgütsel bağlılık çalışanın örgütü benimsemesini ve örgüt için istekli bir şekilde çaba göstermesini ifade etmektedir. Önyargı ise bir kişi veya gruba karşı bilgi eksikliği sebebiyle genellikle olumsuz öngörü sahibi olma durumudur. Alanyazında psikolojik yıldırma ve örgütsel bağlılığa ilişkin çalışmalar olsa da bu kavramları önyargı ile ilişkilendiren bir çalışma bulunmamaktadır. Araştırma örneklemi Ankara ilinde görev yapan 391 öğretmenden oluşmaktadır. Örgütsel bağlllık, psikolojik yıldırma ve önyargı davranışlarını ölçmek için araştırmacı tarafindan alanyazın temel alınarak geliştirilen ölçekler kullanılmıştır. Bu araştırma ilişkisel tarama modeli ile desenlenmiştir. Veriler korelasyon ve hiyerarşik regresyon testleriyle analiz edilmiştir. Araştırmanın sonuçlarına göre mesleki kıdem, yaş ve okul büyüklüğü örgütsel bağllık, psikolojik yıldırma ve önyargı davranışını etkilemektedir. Psikolojik yıldırma ve örgütsel bağllık arasında anlamlı ve negatif bir ilişki bulunmuştur. Önyargı ve örgütsel bağlılı arasında da anlamlı ve negatif bir ilişki belirlenmiştir. Bununla birlikte, önyargı ve psikolojik yıldırma arasında anlamlı ve pozitif yönlü bir ilişki söz konusudur. Hiyerarşik regresyon analizi sonucunda ise önyargının, örgütsel bağlılık ile psikolojik yıldırma davranışı arasında tamamen aracılık ettiği saptanmıştır.
\end{abstract}

Anahtar Kelimeler: Örgütsel Bağılık, Psikolojik Yıldırma, Önyargı, Aracılık

\section{The Mediating Role of Prejudice In}

\section{Mobbing and Organizational Commitment}

\begin{abstract}
This study aims to determine the effect of prejudice on the relationship between organizational commitment and mobbing. Mobbing is the negative actions and behaviors that an employee in an organization applies to other employees. Organizational commitment implies that the employee is adopting an organization and that he/she is trying for the organization willingly. Prejudice is oftentimes a negative prognostication because of lack of information against a person or a group. Although there are studies on mobbing and organizational commitment in the literature, there is no study linking these concepts with prejudice. The research sample consists of 391 teachers working in Ankara. To measure organizational commitment, mobbing and prejudice behaviors, scales developed by the researcher based on the literature were used. This research was designed with correlational survey model. Data were analyzed by correlation and hierarchical regression tests. According to the results of the research, professional tenure, age and school size influence organizational commitment, mobbing, and prejudice. A significant and negative relationship was found between mobbing and organizational commitment. Likewise, a significant and negative relationship was found between prejudice and organizational commitment. However, there is a meaningful and positive relationship between prejudice and mobbing. Because of the hierarchical regression analysis, prejudice was found to be completely mediated between organizational commitment and mobbing.
\end{abstract}

Key Words: Organizational Commitment, Mobbing, Prejudice, Mediation

${ }^{1}$ Dr. Öğr. Üyesi, Muş Alparslan Üniversitesi, e-posta: a.baltaci@alparslan.edu.tr Bu makale URKUND programı yardımıyla intihale karşı kontrol edilmiştir. 


\section{Giriş}

Psikolojik yıldırma (mobbing), ça1ışma yaşamında sıklıkla karşılaşılan bir davranıştır. Kısaca bir çalışanın dışlanması olarak ifade edilebilecek olan psikolojik yıldırma, çalışana karşı örgüt içindeki diğer çalışanlar ve/veya örgüt yöneticileri tarafından yürütülen planl1, sistematik, uzun süreli ve kasıtlı davranışlardır (Lutgen-Sandvik, 2008). Psikolojik yıldırma örgüt içinde taciz, bıktırma, bezdirme gibi baskın davranışlarla görünür hale gelmektedir. Bunun yanında çalışanı rahatsız edebilecek ve onun iş performansını etkileyebilecek her tür dişsal etki (dedikodu, iftira, alay etme, lakap takma vb.), yıldırma olarak belirlenmiştir (Leymann, 1990). Psikolojik yıldırmayı gerçekleştiren aktörler, diğer örgüt çalışanları olduğu kadar örgüt yönetimi de olabilmektedir. Psikolojik yıldırmanın öznesi olan kişi genellikle bu durumdan olumsuz etkilenmekte ve çoğunlukla çalıştığı örgütten ayrılmaktadır. Örgütsel bağlılık, bir çalışanın örgüte olan bağlanma derecesidir (Meyer, 2015). Çalışanın örgütü içselleştirmesi, örgütün hedeflerine ulaşmasını kolaylaştıracaktır. Çalışanların örgüte olan bağlılıklarının artması örgütleri daha çalışılabilir yapabilmektedir. Örgütsel bağlılık, çalışanın örgüt içindeki istekliliğini arttırabilir, ayrıca çalışan aleyhine durumlarda bile örgüt menfaatlerinin ön planda tutulması söz konusudur (Ping, 2015). Örgütsel bağl1lık çalışan için pozitif yönlü bir etki yaratırken, psikolojik yıldırma negatif yönlü bir etki yaratmakta ve çalışanın örgütten ayrılması amacını gütmektedir.

Basit bir anlatımla önyargı, bir şey veya kişiye karşı önceden edinilmiş bir fikir veya tutum içinde olunmasıdır (Allport ve Ross, 1967). Önyargılar, genellikle bilgi eksikliğinden veya önceki deneyimlerimizin genelleştirilmesinden kaynaklanmaktadır. Kişisel önyargıların yanında bir gruba ait olmanın beraberinde getirdiği sosyal önyarg1lar da söz konusudur. Bir grubun, bir kişi ya da bir grup hakkında bilgi eksikliğinden veya sadece kendilerinden farklı olmasından kaynaklanan önyargıları olabilmektedir (Minton, 2014). Genellikle olumsuz ve sabit görüler olan önyargıları değiştirmek oldukça zordur. Örgüt içinde farklı türden davranışın altında önyargılar yatmaktadır. Bir örgütte çalışan bir kişiye karşı önyargılı tutum ve davranışlar içinde olan diğer çalışanların oluşturacağ örgüt iklimi ve çalışma koşulları gerek örgütün etkililiğini ve gerekse çalışanlar arası sosyal uyumu etkileyebilmektedir (Nelson, 2004). Örgüt içinde karşılaş1lan önyargılar çoğu kez değiştirilememekte ve mağdurun örgütü terk etmesiyle sonuçlanabilmektedir.

Okullar sosyal alt sistemler olmas1 sebebiyle çalışanlar arası etkileşimin yoğun olduğu örgütlerdir. Okullarda öğretmenleri yöneticiler ve veliler arasında çeşitli etkileşimler olması doğaldır. Bu etkileşimlerin 
yönü ve içeriğinin öğretmenlerin örgüte olan aidiyetlerinin artmasına neden olabileceği gibi örgüt içinde baskı altına alınmalarına da neden olabilir (Küçükçayır ve Altun, 2016). Bu çalışma alanyazında farklı şekillerde çalışılmış olan örgütsel bağlılık ve psikolojik yıldırma davranışlarının birbirine etkisine ve bu etkileşim içinde önyargının yerinin ne olabileceğine odaklanmakta ve alanyazında bu yönde bulunan önemli bir boşluğu doldurma amacını taşımaktadır. Alanyazında yapılan ilk araştırma olması, araştırmanın öncü karakteristiğine vurgu yapmaktadır. Öğretmenlerin örgütsel bağl1lık düzeylerinin onlara yönelik yıldırma davranışları ile hangi ölçüde farklılık gösterebileceği ve önyargının bu ilişkideki rolünün ne olduğu düşüncesi bu araştırmanın amacıdır. İlerleyen bölümlerde örgütsel bağl1lık, psikolojik yıldırma ve önyargı davranışı ele alınmıştır.

\section{Örgütsel Bağlılık Kavramı}

Örgütler sosyal sistemin önemli parçalarıdır. Sosyal sistem içerisinde farklı üretim görevlerini üstlenen örgütlerin iç mekanizmaları da sosyal bir alt sistemi barındırır. Örgüt içi sosyal etkileşimin önemli bir yönü çalışanlar ile örgüt arasındaki iletişime atıfta bulunmaktadır (Baltacı, 2017). Örgütsel bağl1lık, örgüt içinde çalışanları önemli bir örgütsel davranışıdır. Örgütsel bağlılık, bireyin örgüte olan yüksek derecede ilgisi veya kendisini örgüte adamasıdır (Meyer ve Allen, 1991). Çalışandaki bağlılık düzeyi, onun örgüte olan inanç seviyesini de arttıracaktır. Örgüte inanan bir çalışan, örgütün hedeflerini sahiplenecek ve örgütün değerlerini daha kolay benimseyecektir (Porter, Steers, Mowday ve Boulian, 1974). Örgütsel bağl1lık, çalışanın örgüt içindeki birçok görevde gönüllü olabilmesini ve örgütte uzun süreli iş görmesini de sağlayabilmektedir (Buchanan, 1974).

Örgütsel bağl1lık, çalışanları örgüte bağlayan psikolojik bir duygu yoğunluğu olarak tanımlanmaktadır (O'Reilly ve Chatman, 1986). Örgütsel bağl11ık çalışanın duygusal bağlılığının bir göstergesi olarak tanımlandığında, çalışanın örgütle kurduğu duygusal bağlanma durumu bahis konusu olmaktadır. Duygusal bağlanma, çalışanın kendisini örgütün bir parçası olmaktan memnun olduğu varsayımına dayanmaktadır. Örgütsel bağl1lık belirli bir zaman sürecinde oluşagelen bir duygu yoğunluğudur ve bu haliyle devamlılik arz etmektedir. Devam bağımlılı̆̆ı olarak adlandırılan bu durum, ça1ışanın örgütle ilişiğini kesmede zorlanması, örgütte çalışmayı her şeyden çok istemesi gibi karmaşık ve bağımlı duyguları ihtiva eder. Örgütsel bağlılı̆̆ın bir diğer türünde ise çalışan kendisinin örgüte manen borçlu olduğunu ve bu gönül borcunu örgütte çalışarak ödemesi olarak adlandırılan normatif bağl11ık yer almaktadır (Meyer, 2015; Reichers, 1985; Chun, Shin, Choi ve Kim, 2015). Birbirinden oldukça farklı olan bu bağlılık türleri çalışandan çalışana değişiklik göstermekte ve her çalışanda farklı seviyelerde sergilenebilmektedir (Dhar, 2015). 
Örgütsel bağl1lık örgüt ve çalışanlar için farklı anlamlar içeren bir durumdur. Ça1ışanların sahip olacağı örgütsel bağl1lık seviyesinin artması, örgüt için yüksek düzeyde bir beklentiye neden olabilir (Wood ve Wilberger, 2015). Böylesi bir durumda örgüt, çalışandan daha fazla bireysel performans artışı beklentisi içerisinde olacaktır (Ping, 2015). Bunun yanında yüksek bağl1lık davranışı sergileyen çalışanın örgüt içinde, yöneticilerin ilgisini ve olumlu yönde desteğini görebileceği belirlenebilir (Stevens, Beyer ve Trice, 1978). Örgütsel bağl1lığın sebep olduğu bireysel performans artışı, örgütün performansını arttıracak ve bu sayede düşük çalışan devamsızlığı gibi olumlu örgütsel etkileri olacaktır (Hofman ve Newman, 2014). Örgütsel bağl1lık düşük seviyelerde de sergilenebilmektedir. Böylesi bir durum çal1şanda örgütsel bağlılığın olmadığı anlamına gelmemektedir. Düşük seviyede örgütsel bağl1lığa sahip olan çalışanlar, örgüte daha az ilgi duymakta ve örgüt yönetimince daha kolay gözden çıkarılabilmektedir (Green, Dishop ve Aarons, 2016).

Örgütsel bağl1lık, çalışanların örgüte tam olarak uyum sağlaması, örgütün amaçlarını içselleştirmesi, bu içselleştirmenin devamlı olması ve örgüte içten bir sadakatle bağlanmasıdır (Meyer ve Allen, 1991). Örgütsel bağlılık davranışında hem çalışan ve hem de örgüt için bir karşılıklı çıkar ilişkisi de bulunabilmektedir. Bu haliyle çıkarlar için bir araç olarak kullanılan bağlılık davranış1, O’Reilly ve Chatman'a (1986) göre uyum, özdeşleştirme ve içselleştirme olarak belirlenebilen üç alt boyutta incelenmiştir. Örgütsel bağl1lı̆̆ın 'uyum' boyutunda çalışanlar, örgüte daha az bağl1lık hissetmekte ve çıkarları doğrultusunda zorunlu olarak örgütte kalmaktadırlar (Biswas ve Bhatnagar, 2013). Bu boyutta çalışanlar genellikle daha somut kazançlara ve çıkarlarına odaklanmışlardir (Avolio, Zhu, Koh ve Bhatia, 2004). Özdeşleşme boyutundaysa çalışanlar enformel iletişim söz konusudur. Bu boyutta çal1şanlar, örgütün değerlerini benimsemekte gerek yöneticilerle ve gerekse diğer çalışanlarla sosyal iletişim kurmakta ve kendilerini örgüt içinde var etmeye ve örgütün bir üyesi olmaya çalışmaktadırlar (Cook ve Wall, 1980; Porter, Steers, Mowday ve Boulian, 1974). Örgütsel bağl1lığın içselleştirme boyutundaysa çalışanlar örgütü sahiplenmiş ve kendilerini örgüt ile bütünleşmiş bir biçimde görmektedirler. Bu boyutta çalışanlar örgütün amaç ve değerlerini tam olarak benimsemiş ve kendi amaç ve değerleri haline getirmişlerdir (Tett ve Meyer, 1993). İçselleştirme boyutu, örgütsel bağl1lığın en üst derecesidir (Meyer, 2015).

Çalışanların örgüte olan bağl11ıkları hem kendi özellikleri ve hem de örgüt kaynaklı değişkenler tarafından yönlendirilmektedir. Örgütsel bağl1l1k, bireysel, örgütsel ve çevresel unsurlardan etkilenmektedir. Bireysel faktörler, cinsiyet, yaş, etnik köken gibi çalışanların sahip oldukları kişisel özellikleridir (Balay, 2000). Kişisel özellikler, çalışanların örgütle olan etkileşiminde temel belirleyicidir. Çalışanın uyumlu kişilik özellikleri sergilemesi onun gerek yöneticiler ve 
gerekse diğer çalışanlarca daha kolay kabul görmesini sağlayabilir (Hofman ve Newman, 2014). Örgütsel faktörler, örgütün yapısı, çalışanlar arası roller, adil bir ödül ve ceza sistemi, örgüt içi iletişim, çalışanlar arasındaki uyum gibi örgüt kaynaklı unsurlardır. Çalışanların örgütsel bağlılıklarında örgüt kaynaklı unsurlar önemli bir yere sahiptir. Dengeli bir iklime sahip örgütler amaçlarına daha kolay ulaşırken çalışanlar da böylesi örgütlere daha fazla bağl1lık göstermektedirler. Çevresel faktörler ise örgütün içinde bulunduğu rekabet ortamı, örgütün imaj1, yasal düzenlemeler ve üst sistemlerle ilişkiler gibi unsurları içermektedir (Tett ve Meyer, 1993; Dhar, 2015). Çalışanlar için çalıştıkları örgütün toplum içindeki imaj1 ve diğer örgütlerle rekabet edebilir bir konumda olması örgütsel bağl11ıklarını artt1rabilmektedir (Wood ve Wilberger, 2015).

Eğitim örgütleri, sosyal etkileşimin yoğun olduğu yapılardır. Okullarda profesyonel olarak çalışan öğretmenler, yöneticiler ve diğer çalışanlar ile veliler ve öğrencilerin karş1ıklı etkileşimi farklı türden bağlılık davranışlarının sıklıkla sergilenmesini gerektirmektedir. Okulu bir üretim örgütü olarak tanımladığımızda, öğretmenler, okullardaki başlıca çalışanlar olarak belirmektedir. Öğretmenlerin okula bağlılı̆̆1, duygusal, devam ve normatif bağlılı̆̆ın farklı seviyelerini içerebilen dinamik bir süreci ifade etmektedir (DiPaola ve Tschannen-Moran, 2014). Bunun yanında öğretmenlerin örgütlerini içselleştirdikleri ve örgütlerine yüksek düzeyde bağl1lık gösterdikleri de belirlenmiştir
(Balay, 2000). Okullarda karşılaşılan örgütsel bağlılık davranışı araştırmaları çoğunlukla yönetici veya öğretmenlerin bağl1lık düzeylerinin ölçülmesi veya farklı örgütsel davranış türlerinin (örgütsel adalet, örgütsel sessizlik vb.) birbiri ile ilişkilendirilmesi şeklinde süregelmiştir. Örgütsel bağl1l1k, kapsaml1, dinamik ve çok yönlü bir davranıştır ve bu davranışın farklı değişkenlerle sınanması onun karmaşık yapısının aydınlatılması açısından önem taşımaktadır. $\mathrm{Bu}$ araştırmada örgütsel bağl11ık davranışı ile psikolojik yıldırma ve önyargı davranışı arasındaki ilişkiler incelenmiştir. Bu araştırmanın konusunu oluşturan psikolojik yıldırma davranışı ilerleyen bölümde incelenmiştir.

\section{Psikolojik Yıldırma Kavramı}

Psikolojik yıldırma (mobbing), iş yerlerinde çalışanlar arasında yaşanan olumsuz etkileşim durumları olarak tanımlanmaktadır (Leymann, 1996). Bunun yanında, iş yerinde bir ya da daha fazla çalışan tarafından yine bir veya bir grup çalışana karş1 uzun bir süre olumsuz eylem ve davranış sergilenmesi, psikolojik yıldırma olarak tanımlanabilir (Leymann, 1990; Zapf, 1999). Psikolojik y1ldırma, genellikle sistematik bir önyargı eğilimini ve belirli bir çalışana karşı girişilen olumsuz eylem ve davranışları kapsamaktadır (Niedl, 2004). Olumsuz eylem ve davranışların sıklığı ve şiddeti, çalışanların fiziksel ve ruhsal rahatsızlıklar yaşamasına ve hatta örgütten ayrilmasına neden olabilmektedir (Hubert ve Van Veldhoven, 2001). Psikolojik yıldırma, çalışanların karşılaşabi- 
leceği önemli bir stres faktörü olarak görülmektedir (Curio, Ernst ve Vieth, 1978). Örgütlerde yaşanan psikolojik yıldırma sürecinde mağdur, farklı türden olumsuz eylem ve davranışlarla karşı karşıya kalmaktadır (Einarsen, 1999). Bu olumsuz eylem ve davranışlar, öncelikle yalnızca bir çalışan tarafından gerçekleştirilirken daha sonra örgüt içinden diğer çalışanlarında katılımıyla bir grup ve hatta örgütte çalışanların tamamı tarafindan sergilenmektedir (Vartia, 1996). Psikolojik yıldırma davranışına maruz kalan genellikle örgüt içi sosyal bir yalıtıma uğramakta, damgalama (stigmatization) ve şeytanlaştırma (demonization) gibi farklı durumlarla karşı karşıya kalabilmektedir (Leymann ve Gustafsson, 1996). Psikolojik y1dırma, örgüt içinde bir çalışana karşı girişilen ahlak dışı bir eğilim dizgesi olmakla birlikte, incitici ve yıpratıcı sözler söyleme ve küfür etme gibi durumları, cinsel taciz ve tecavüz veya fiziksel istismar gibi konusu suç teşkil eden pek çok eylemi de kapsamaktadır (Lutgen-Sandvik, 2008). Psikolojik yıldırma davranışının faili ise, mağduru sindirerek veya yıldırarak örgütte kendi gücünü meşrulaştırmakta veya örgütü terk etmesini sağlamaktadır (Niedl, 2004).

Psikolojik yıldırma, sistematik olmasının yanında failler tarafından önceden planlanmış bir eylem ve davranış dizgesine de sahiptir (Leymann, 1996). Çalışanlara yönelik taciz, tehdit, korkutma, zorbalık ve saldırganlık gibi çoğu durum önceden planlanmaktadır. Olumsuz eylem ve davranışları sergileyen failler genellikle konusu suç teşkil eden durumları daha dikkatli planlamakta, mağdurların çatışmayı engelleme davranışlarına karşı kayıtsız kalmaktadırlar (Martin ve Peña, 2012). Böylesi bir kayıtsızl1k, mağdurda da görülebilmektedir. Mağdur, kendisine karşı sürdürülen yıldırma amaçlı eylem ve davranışları önemsemiyor veya böylesi bir durumu fark etmiyor da olabilir (Keim ve McDermott, 2010). Mağdur tarafından algılanmasa da örgütlerde yaşanan yıldırıcı olumsuz eylem ve davranışlar, diğer çalışanlar için önemli bir stres kaynağı olmaktadır. Diğer çalışanlar, kendilerine de böylesi yıldırıcı bir eylem ve davranış dizgesinin yönelebileceğinin farkındadırlar (Duffy ve Sperry, 2007).

Psikolojik yıldırma, bir çalışana, başka bir çalışanın zulmetmesidir. Genellikle örgüt yöneticileri psikolojik yıldırmanın faili olabilirken, mağdur bir çalışan veya örgütün bir paydaşı da olabilir (Cemaloğlu, 2007). Örgütün yapısından kaynaklı olumsuzluklar; örgüt yöneticilerinin yetersizliği, mağdurun psikolojik, fiziksel veya sosyal açıdan yetersizliği ve diğer çalışanların sahip olduğu düşük etik değerler, örgütlerde psikolojik yıldırmanın görülmesinde etkili olabilmektedir (Branch, Ramsay ve Barker, 2013). Ayrıca çoğu durumda örgüt içinde yaşanan kıskançlıklar ve dedikodu gibi enformel sosyal süreçler de yıldırma sebebi olabilmektedir (Rivers ve Smith, 1994). Örgüt içinde belirgin bir denetim olmamas1, yöneticilerin astlarını denetlememeleri; çalışanlar arasındaki rekabet, örgüt içinde ödül 
ve ceza prosedürlerinin belirlenmemiş olması; ödül beklentisi gibi çeşitli etmenlerin de yıldırma davranışının görülmesinde etkili olduğu belirlenmiştir (Crawshaw, 2009). Psikolojik yıldırma davranışının görülmesinde mağdurun kişilik özellikleri de önemlidir. Mağdurun sakin, teslimiyetçi veya saldırgan kişilik özelliklerinde olması veya örgüt içinde diğer çalışanları olumsuz etkileyebilecek bir karaktere sahip olması, psikolojik yıldırma davranışının oluşmasında etkilidir (Salin, 2003; Niedl, 2004). Psikolojik yıldırma nadiren fiziksel şiddet içermektedir (Lewis, 1999). Ancak yıldırma süreci, belirli bir düzeyde saldırgan ve kışkırtıcı davranışlar, zorbalık, asılsız damgalama, yalnızlaştırma gibi psikolojik şiddet unsurlarını da kapsar (Keim ve McDermott, 2010). Mağdur sürecin her aşamasında ciddi travmalar yaşayabilmekte; giderek örgütten soyutlanmakta ve çoğunlukla örgütten ayrılmaktadır (Duffy ve Sperry, 2007). Psikolojik y1ldırmada failler, mağdurlar ve izleyicilerden oluşan üç farklı rol takımından bahsedilebilir. Failler, yıldırmanın ana uygulayıcılarıyken, mağdurlar olaydan etkilenen kitledir; bunun yanında izleyicilerse örgütte yaşanan olayları dışarıdan izleyen çalışanlardır. Failler aktif bir rol etkinliğine sahipken, mağdur ve izleyiciler genellikle pasif bir konumdadır (Leymann, 1996).

Eğitim örgütlerindeki çalışanlar arasında psikolojik yıldırma davranışlarına sıklıkla rastlanılmaktadır. Eğitim örgütlerinde üstler (okul müdürü ve diğer üst yöneticiler vb.), genellikle ast durumunda olanlara (öğretmenler ve diğer çalışanlar) karşı yaygın olarak yıldırma davranışları sergilemektedirler (Şener, 2013; Küçükçayır ve Altun, 2016). Bununla birlikte, aynı konumdaki çalişanlar arasında (öğretmenler veya diğer çalışanlar arasında) veya astların üstlerine (öğretmenlerin okul müdürlerine vb.) karşı yı1dırma davranışı sergilediği de bildirilmektedir (Özgan, Kara ve Arslan, 2013). Okullarda yaşanan dedikodu, damgalama, yalnızlaştırma gibi durumlar çoğunlukla aktif yıldırma davranışlarıdır ve mağdurlar genellikle örgütten ayrilmakta veya ceza alabilmektedir (Erdemir ve Murat, 2014). Okullarda yaşanan yıldırma davranışlarının incelenmesi, okullardaki çalışma koşullarının, çalışanlar arasındaki ilişkilerin durumunun ve örgütün ikliminin belirlenmesi için önem arz etmektedir. İlerleyen bölümde bu çalışmanın başka bir konusu olan önyargı kavramı incelenmiştir.

\section{Önyargı Kavramı}

Önyargı, bir şey ya da kişi hakkında belirgin bir neden veya delile dayanmaks1zın, önceden geliştirilen olumlu veya olumsuz bir fikir veya yargilardır (Baltacı, 2017). Önyargılar, sabit ve değişmeye dirençli fikirlerdir (Devine, 1989). Genellikle önyarg1lara olumsuz bir anlam yüklenmekle birlikte, bir şeye veya kişiye karşı geliştirilen olumlu önyargılarda söz konusu olabilmektedir (Dovidio ve Gaertner, 1986). Belirli bir gruba veya o grubun bir üyesine karşı, yalnızca o grubun bir üyesi olmasından dolayı veya haklı bir neden olmaksızın geliştirilen 
ve tarafgirlik içeren düşünce ve tutumlar da önyargı olarak adlandırılmaktadır (Allport ve Ross, 1967). Çoğunlukla olumsuz bir yönelimi olan önyargılar, kişiler arasında oluşabileceği gibi gruplar arasında da oluşabilen kötü niyetli düşünce ve tutumlardır (Duckitt, 1992). Örgütsel önyarg1, örgütlerde yaşanan önyargılar olmakla birlikte, çoğunlukla bir çalışana, başka bir örgüte veya paydaşlara ilişkin olabilir (Van Dijk, 1987). Örgütsel önyargılar, bir kişi veya grup hakkında doğruluğu ispat edilmemiş ve çoğu kez hayatın gerçekleriyle örtüşmeyen kuvvetli ve olumsuz tutumlardır (Meyer, 2003). Bunun yanında örgüt içinde yaşanan önyargılar, bir kişi veya bir grup çalışana karşı haklı olmayan, hoşgörüsüz, asılsız görüşler ve tutumlardır. Örgütlerde yaşanan önyargılı tutumlar, çalışanları benzer ortak karakteristiklerine göre kümeleyerek aynı küme içinde yer alan tüm çalışanların aynı özellikte olduğu öngörüsünden hareket etmektedir. Böylesi bir tutum gerçekte çal1şanları kategorize etme eğilimi olarak görülmektedir (Blumer, 1958). Örgütlerde yaşanan önyargilar soyut ve somut olarak rahatlikla belirlenebilmektedir (Eagly ve Karau, 2002). Örgüt içinde bir çalışana karşı önyargılı davranışlar zaman içinde farklı örgütsel davranışlara (yıldırma, damgalama vb.) evirilebilir (Lutgen-Sandvik, 2008). Böylesi bir durum örgüt içinde yaşanan önyargıların ne denli önemli olduğuna vurgu yapmaktadır.

Örgütlerde çalışanlar cinsiyet, yaş, din, etnik köken, ten rengi, siyasi veya cinsel tercih gibi çok çeşitli özellikleri sebebiyle önyargılı tutumlarla karşılaşabilmektedirler. Çalışanların belirli kategorilerde değerlendirildiği böylesi bir önyargılı yaklaşım zamanla çeşitli olumsuz eylem ve davranışlara dönüşmektedir (Kinder ve Sears, 1981). Örgüt içinde yaşanan önyargılı davranışlar aşağılayıcı veya alay edici şakalar, hakaretler, tehdit, iftira ve sözlü veya fiziksel taciz gibi durumlarını; daha ileri düzeyde ise saldırganlık, fiziksel şiddet gibi konusu suç teşkil edebilen eylemleri de kapsamaktadır (Pettigrew ve Meertens, 1995). Bunun yanında örgütlerde karşılaşılan önyargıların: örgüt içi ödeme ve ikramiyelerde yanlı davranma, ödemelerde yapılan fazladan kesintiler, örgüt içindeki çeşitli etkinliklerden sistematik bir şekilde yalıtma, sürekli ve sık1 denetleme, yüksek standartlar veya gerçekleştirilemeyecek hedefler belirleme, çalışma koşullarını zorlaştırma gibi daha gizli bir motifte sürdürüldüğü de belirlenmiş̧tir (Fiske, 2000; Baltac1, 2017).

Örgütlerde, engelli, yaşlı, kadın çalışanlar ile dini ve etnik açıdan örgüt içinde diğer çalışanlardan önemli ölçüde farklılık gösteren çalışanlar genellikle çeşitli önyargılı tutum ve davranışlarla karşıllaşabilmektedirler (Ponterotto ve Pedersen, 1993). Böylesi olumsuz bir durum çalışanın psikolojisinin bozulmasına ve dolayısıyla örgütün etkililiğinin azalmasına neden olabilmektedir (Tajfel, 1969). Örgütlerde yaşanan önyargılı davranışlar astlar arasında olabildiği kadar, astlardan üstlere ve üstlerden astlara da yönelik olabilir (Kinder ve Sears, 1981). Hatta çoğu durumda örgüt içinde önyargılı tutum 
ve davranışlarla karşılaşan çalışanlar, karşı bir düşünce geliştirmekte ve örgüte karşı önyarg1 içinde olabilmektedir (Meyer, 2003). Örgütlerde yaşanan önyargılı davranış ve tutumlar kişisel olmaktan öte örgüt siyasalarına da dönüşebilmektedir. Böylesi önyarg1lara, özellikle örgüte yeni bir üye katılımında veya örgüt içi terfilerde rastlanılmaktadır. Örgüt içinde işe alma veya terfi sürecinde aktif olarak yer alan karar vericiler, kendilerine benzer özelliklere sahip çalışanları işe alma veya terfi ettirmeye eğilimli olmaktadırlar (Dovidio, Glick ve Rudman, 2005). Böylesi bir durum, örgüt yöneticilerinin kendilerine uygun bir örgüt iklimi oluşturma çabas1 ve bir tür avantaj durumu olarak değerlendirilebilirken, gerçekte işin gerektirdiği yeteneklerle donanmış ve nitelikli kişilerin göz ardı edilmesine neden olabilmektedir (Van Dijk, 1987). Örgütlerde yaygın olarak karşılaşılan önyargılar ve bunların neden olduğu olumsuzluklar, eğitim örgütlerinde de söz konusudur. Özel okullardan farklı olarak resmi okullarda, çalışanların seçilmesi merkezi bir atama usulüyle yapıldığından, herhangi bir etnik köken, cinsiyet, din ve kültürel farklılığa sahip çalışanların bulunması olasıdır. Böylesi bir çeşitliliğe sahip okullarda sosyal uyumu sağlamak ve çalışanlarda önyargı oluşumunu engellemek güçlükler içermektedir. Okullarda nitelik ve niceliksel olarak baskın grupların dışında kalan kişi ve gruplara (dış gruplar) karşı önyargılar gelişebilmektedir (Allport ve Ross, 1967; Pettigrew ve Meertens, 1995). Okullarda söz konusu olan önyargılar, öğretmenler arasında veya öğretmenlerle yöneticiler arasında olabildiği gibi öğrenci ve velilerin aktörü olduğu çeşitli önyargı durumları da söz konusudur. Örneğin öğretmenin dini tercihleri veya yöneticinin cinsiyeti ya da öğrencinin etnik kökeni belirgin bir önyargı oluşturmaktadır (Eagly ve Karau, 2002). Okullarda yaşanan önyargı tutum ve davranışlarının incelenmesi, okullardaki sosyal etkileşimleri görünür kılabilir. Ayrıca önyargıların engellenmesine yönelik çalışmaların eğitim sistemine eklemlenmesiyle önyargı araştırmalarının, önemli bir toplumsal etkisinin olacağı da düşünülmektedir.

Alanyazında psikolojik yıldırma ve örgütsel bağl1lık arasındaki ilişkiyi inceleyen araştırmalar bulunmaktadır (Şener, 2013; Karcıoğlu ve Çelik, 2012; Pelit ve K111ç, 2012). Bu araştırmalarda çoğunlukla psikolojik yıldırma ve örgütsel bağl1lı̆̆n ters yönlü bir ilişkiye sahip olduğu belirlenmiştir. Bununla birlikte örgütsel bağlılık ve önyargı veya psikolojik yıldırma ve önyarg1 arasındaki ilişkinin göz ardı edildiği görülmektedir. Bu araştırma alanyazında eksikliği belirlenen bir boşluğu giderme niyetiyle yapılmıştır. Araştırmanın amacı, öğretmenlerin örgütsel bağl1lık düzeylerinin, onlara yönelik psikolojik yıldırma davranışları ile ilişkisinde önyargının aracılık rolünün belirlenmesidir. Bu amaçla aşağıdaki hipotezler geliştirilmiştir:

Hipotez 1: Öğretmenlerin örgütsel bağl1l1k düzeyleri, onlara yönelik psikolojik yıldırma davranışlarını olumlu yönde etkilemektedir. 
Hipotez 2: Öğretmenlerin örgütsel bağl1l1k düzeyleri, önyargılarını olumlu yönde etkilemektedir.

Hipotez 3: Öğretmenlere yönelik psikolojik yıldırma davranışları, öğretmenlerin önyargılarını olumlu yönde etkilemektedir.

Hipotez 4: Öğretmenlerin örgütsel bağl1lıkları ile onlara yönelik psikolojik yıldırma davranışları arasındaki iliş̧ide önyargının aracılık etkisi vardır.

\section{Yöntem}

\section{Araştırma Deseni}

Araştırmada nicel araştırma yöntemlerinden nedensel karşılaştırmalı araştırma deseni kullanılmıştır. Bu kapsamda araştırmada öğretmenlerin, örgütsel bağl1lığın içselleştirme, özdeşleşme ve uyum boyutlarındaki özellikleri gösterme düzeyleri ile onlara yönelik psikolojik yıldırma davranışlarını ve öğretmenlerin önyargı davranışlarını belirlemek amaciyla 'örgütsel bağl1lık', 'psikolojik yıldırma' ve 'önyargı' ölçekleri kullanılmıştır. Daha sonra her üç davranış arasındaki ilişkiler korelasyon ve hiyerarşik regresyon yöntemiyle incelenmiştir.

\section{Örneklem}

$\mathrm{Bu}$ araştırmanın evrenini, Ankara'daki 2.631 okulda (Anaokulu, ilkokul, ortaokul ve lise) çalışan 67.969 öğretmen oluşturmaktadır. Araştırmanın örneklemi ise olasılıklı örneklem tekniklerinden biri olan tabakalı örnekleme tekniği kullanılarak belirlenmiştir. Örneklemde bulunan öğretmenlerin belirlenmesinde, evrendeki ayrıntıların örneklemde de temsil edilmesine olanak tanıyan, olasılığa dayalı örnekleme biçimlerinden tabakalı örnekleme tekniği kullanılmıştır (Neuman, 2014). Örneklem büyüklüğü güç analizi le belirlenmiş; bu doğrultuda evrenden çekilen ve örnekleme yansitılan say1ların hesaplanmasında Cochran'in (2007) tabakalı örneklemede örneklem büyüklüğünü saptamada yaygın olarak kullanılan formülü kullanılmıştır. İlgili örneklem hesaplamaları formülü kullanılarak evreni .05 anlamlılık ve $\% 5$ hata payı ile temsil edecek örneklem sayıs1 382 olarak belirlenmiştir. Araştırmada kullanılan tabakaların oluşturulmasında 25 ilçede bulunan öğretmen sayıları dikkate alınmış, ayrıca cinsiyet, yaş ve mesleki kıdem değişkenlerinin evrende var olduğu biçimde temsil edilmesi için azami çaba gösterilmiştir. İlçelerin tabakalara ayrılmasında ise Ankara İlini beş yaşam kalitesi düzeyine göre sinıflandiran Şeker'in (2011) sinıflandırması kullanılmıştır. Araştırmada kullanılan anket formu Ankara İlinin 25 ilçesinde yer alan okullara araştırmacı tarafindan elden veya e-posta ile ulaştırılmış ve katılımc1lara araştırma konusu hakkında bilgi verilerek yeterli süre içinde ölçme araçlarını doldurmaları istenmiştir. Doldurulan anket formları, yine elden araştırmacı tarafından veya e-posta kanalıyla toplanmıştır. Katılımcılara (öğretmenler), 500 anket formu gönderilmiş, 417'si geri dönmüştür. Bu formlardan 19'u eksik veya yanlış doldurma, 7'si de uç değerler nedeniyle analizden çıkarılmıştır. Belirlenen örneklem büyüklüğünü karşılayan 391 anket formu analize dâhil edilmiştir. Araştırmada kullanılacak olan anket 
formlarının ön uygulaması ana araştırmaya katılmayan ve örneklem özelliklerini taşıyan Ankara'nın farklı ilçelerinde görev yapan 109 kişilik bir öğretmen örneklemi üzerinde yapılmıştır. Araştırmanın ana uygulamasına katılan öğretmenlerin \%53,7'u kadındır; \%36,3'ü 31-40 yaş; \%31,8'inin mesleki k1demi 10-15 yıl ve \%69,6'sı lisans düzeyinde eğitim almıştır. Araştırmaya katılan öğretmenlerin çalıştıkları okullar çalışan sayılarına göre değerlendirildiğinde ise \%22,7'sinin küçük ölçekli okullar (çalışan sayısı 10'dan az,) \%51,4'ünün orta ölçekli okullar (çalışan sayısı 10-50 arası) ve \%25,9'unun ise büyük ölçekli okullardır (çalışan sayısı 50-250 aras1).

\section{Veri Toplama Aracı}

Araştırmada yer alan veriler anket yöntemi ile toplanmıştır. Söz konusu ankette öğretmenlere ait demografik bilgilerin yanı sıra araştırmada kullanılacak değişkenlere ve kontrol değişkenlerine ait ölçekleri içeren dört bölüm bulunmaktadır. Ölçek, likert tipi beşli dereceleme türünde hazırlanmıştır. Likert tipi ölçekte yer alan maddeler: (5) "Her zaman" ve (1) "hiçbir zaman" şeklinde puanlanmaktadır.

Psikolojik Yıldırma Ölçeği, Einarsen ve Raknes (1997)'in geliştirdiği 'Olumsuz Davranış Soruları' ölçeği ve Leymann (1990) tarafından geliştirilen 'Psikolojik Terör Envanteri' ölçeği temel alınarak araştırmacı tarafindan hazırlanmıştır. Psikolojik Yıldırma Ölçeğinin yapı geçerliğini sınamak için araştırma sürecinde toplanan ön uygu- lama verileri üzerinde öncelikle normal dağılım incelemeleri yapılmıştır. Bu noktada, Analiz için Kaiser-Meyer-Olkin (KMO) değeri 0,987 ve Barlett's testi anlamlı $(\mathrm{p}<0.01)$ bulunmuştur. Verilerin faktör analizi için uygun olduğu belirlenmiştir. Daha sonra veri setine açımlayıcı faktör analizi uygulanmıştır. 32 maddelik taslak ölçekten faktör yük değeri .30'den düşük olan 6 madde ile binişik olan iki madde çıkarılmıştır. 2 madde de madde toplam korelasyonu $.25^{\prime}$ den daha küçük olduğu için çıkarılmıştır. Ön uygulama verilerinden hareketle faktör analizi sonucunda belirlenen 22 maddenin tek faktöre dağıldı ğı ve ölçeğinin hesaplanan Cronbach Alpha katsayısı $(\alpha=.87)$ ile doğrulanan Bileşik güvenirlik katsayısı değeri 91 olarak belirlenmiştir. Ölçeğin ayrışım geçerliliğini belirlemek üzere doğrulayıcı faktör analiziyle gerçekleştirilmiştir. Doğrulayıcı faktör analizi sonucunda ölçeğin tek modele sahip olduğu ve uyum iyiliği değerlerinin $\left(\chi_{(336)}^{2}=762.70, \quad \chi^{2} / \mathrm{sd}=2.27 \quad \mathrm{RMSEA}=.081\right.$, GFI=.96, CFI=.93, IFI=.92, SRMR=0.06, NNFI=.90, AGFI=0.91) kabul edilebilir değerlerde olduğu görülmüştür. Bu sonuçlara göre, araştırmadan elde edilen verilerin psikolojik yıldırma davranışının tek faktörlü modeli ile uyuştuğunu ve toplam varyansın \%76,82'sini açıkladığını göstermiştir.

Örgütsel bağlılık davranışı Allen ve Mayer (1990) tarafindan geliştirilen ve Meyer, Allen ve Smith (1993) tarafindan güncellenen ölçekten ve Porter, Steers, Mowday ve Boulian (1974) tarafından geliştirilen öl- 
çeklerden faydalanılarak araştırmacı tarafindan geliştirilmiştir. Örgütsel Bağlılık Ölçeğinin yap1 geçerliğini sınamak üzere ön uygulama değerleri üzerinde normal dağılımı incelemesi yapılmıştır. Bu bağlamda, Analiz için Kaiser-Meyer-Olkin (KMO) değeri 0,979 ve Barlett's testi anlaml $(\mathrm{p}<0.01)$ bulunmuştur. Veriler faktör analizi için uygundur; ardından veri setine açımlayıcı faktör analizi uygulanmıştır. 38 maddelik taslak ölçekten faktör yük değeri .35 'den düşük olan sekiz madde ile binişik olan üç madde atılmıştır. Dört madde de madde toplam korelasyonu $.25^{\prime}$ den daha küçük olduğu için atılmıştır. Ön uygulama verilerinden hareketle faktör analizi sonucunda belirlenen 23 maddenin üç faktöre dağıldı ̆̆ belirlenmiştir. Örgütsel Bağl1lık Ölçeğinin hesaplanan Cronbach Alpha katsayısı ve doğrulanan Bileşik güvenirlik katsayısı değerleri Tablo 1 'de görülmektedir.

Tablo 1. Örgütsel Bağlılık Ölçeğinin Güvenilirlik Katsayıları

\begin{tabular}{lllll}
\hline Faktörler & $\overline{\mathbf{X}}$ & $\mathbf{S S}$ & $\begin{array}{l}\text { Cronbach Alpha } \\
(\boldsymbol{\alpha}) \text { Katsayısı }\end{array}$ & $\begin{array}{l}\text { Bileşik Güvenirlik } \\
\text { Katsayısı }\end{array}$ \\
\hline Uyum & 51.78 & 6.03 & 0.85 & 0.88 \\
Özdeşleşme & 52.67 & 6.37 & 0.87 & 0.91 \\
İçselleştirme & 47.41 & 6.49 & 0.84 & 0.86 \\
\hline
\end{tabular}

Örgütsel Bağl1lı Ölçeğinin ‘uyum’ boyutu için iç tutarlılık katsayısı $(\alpha) .85$ ve bileşik güvenirlik katsayısı .88; 'özdeşleme' boyutu için iç tutarlılık katsayısı $(\alpha) .87$ ve bileşik güvenirlik katsayısı .91 ve 'içselleştirme' boyutu için iç tutarlılık katsayısı $(\alpha)$ .84 ve bileşik güvenirlik katsayısı .86 olarak belirlenmiştir. Örgütsel Bağlllık Ölçeğinin her üç alt boyutu için belirlenen güvenirlik katsayılarının tamamı bir ölçekte bulunması tavsiye edilen güvenirlik sınırı olan.70 (Cortina, 1993; Sijtsma, 2009) şartını karşılaşmaktadır. Ölçeğin tamamına ilişkin toplam Cronbach Alpha güvenirlik katsayısı .86 ve bileşik güvenirlik katsayısı .89 olarak hesaplanmıştır. Doğrulayıcı faktör analizi sonucunda ölçeğin üç boyutlu modelinin $\left(\chi_{(366)}^{2}=782.56, \quad \chi^{2} / \mathrm{sd}=2.13, \quad \mathrm{p}=0.00\right.$, $\mathrm{CFI}=0.93, \quad \mathrm{NFI}=0.91, \quad \mathrm{SRMR}=0.06$, RMSEA $=0.04, \quad \mathrm{IFI}=.92, \quad \mathrm{GFI}=0.89$, AGFI=0.91) oldukça iyi bir uyum gösterdiği belirlenmiştir. Bu sonuçlara göre, araştırmadan elde edilen verilerin örgütsel bağlllık davranışının üç faktörlü modeli ile uyuştuğunu ve üç faktörün, toplam varyansın \%79,88'ini açıkladığı belirlenmiştir. 
Önyargı Ölçeği, Asamen ve Barry (1987), Masson ve Verkuyten (1993), Castro (2010) ile Meertens ve Pettigrew (1992) ölçeklerinden faydalanılarak araştırmacı tarafından geliştirilmiştir. Önyarg1 Ölçeğinin yapı geçerliğini sınamak için araştırma sürecinde toplanan ön uygulama verileri üzerinde öncelikle normal dağılım incelemeleri yapılmıştır. Bu noktada, Analiz için KaiserMeyer-Olkin (KMO) değeri 0,991 ve Barlett's testi anlamlı $(\mathrm{p}<0.01)$ bulunmuştur. Verilerin faktör analizi için uygun olduğu belirlenmiştir. Daha sonra veri setine açımlayıcı faktör analizi uygulanmıştır. 21 maddelik taslak ölçekten faktör yük değeri .35 'den düşük olan dört madde ile binişik olan bir madde atılmıştır. İki madde de madde toplam korelasyonu $.25^{2}$ den daha küçük olduğu için atılmıştır. Ön uygulama verilerinden hareketle faktör analizi sonucunda belirlenen 14 maddenin tek faktöre dağıldığ ve ölçeğinin hesaplanan Cronbach Alpha katsayısı $(\alpha=.91)$ ile doğrulanan Bileşik güvenirlik katsayısı değeri .94 olarak belirlenmiştir. Ölçeğin ayrışım geçerliliğini belirlemek üzere doğrulayıcı faktör analiziyle gerçekleştirilmiştir. Doğrulayıcı faktör analizi sonucunda ölçeğin tek modele sahip olduğu ve uyum iyiliği değerlerinin $\left(\chi_{(312)}^{2}=746.58\right.$, $\chi^{2} / \mathrm{sd}=2.39 \quad \mathrm{RMSEA}=.089, \quad$ GFI $=.98$, $\mathrm{CFI}=.96, \mathrm{IFI}=.95, \mathrm{SRMR}=0.07, \mathrm{NNFI}=.94$, AGFI=0.96) kabul edilebilir değerlerde olduğu görülmüştür. Bu sonuçlara göre, araştırmadan elde edilen verilerin önyargı davranışının tek faktörlü modeli ile uyuştuğunu ve toplam varyansın \%77,12'sini açıkladığını göstermiştir.
Araştırmada kullanılacak olan değişkenlerin ayrışım geçerliliğini doğrulayıcı faktör analiziyle yapılan sınamada; üç faktörlü (üç faktörlü örgütsel bağl1l1k + önyarg1 + psikolojik yıldırma) modele ait uyum iyiliği istatistiklerin $\left(\chi^{2}{ }_{(384)}=656.26, \chi^{2} / \mathrm{sd}=1.70\right.$ RMSEA $=.084$, GFI=.90, CFI=.93, IFI=.92, SRMR=0.06, NNFI=.92, AGFI=0.92) kabul edilebilir değerlerde olduğu görülmüştür. Araştırmada kullanılan kontrol değişkenleri için ise ilgili alanyazındaki öneriler doğrultusunda öğretmenlerin cinsiyeti, yaşı ve mesleki kıdem ile okul büyüklüğü analiz işlemlerinde dikkate alınmıştır.

\section{Verilerin Analizi}

Öğretmenlerin örgütsel bağl1lık, psikolojik yıldırma ve önyargı davranışlarının, cinsiyet, yaş, meslek kıdemi ve okulun büyüklügüne göre ilişkilerinin belirlenmesinde korelasyon ve hiyerarşik regresyon testleri kullanılmıştır. Aracılık düzeyinin ve modele etkisinin anlamlı bir şekilde belirlenebilmesi için Sobel testi kullanılmıştır. Manidarlık sınamaları $\alpha=0.05$ anlamlılık düzeyinde gerçekleştirilmiştir.

\section{Bulgular}

Araştırmada öncelikle değişkenler arası ilişkilerin düzeyini tespit etmek için korelasyon analizi yapılmıştır. Tablo 2'de araştırmanın ana değişkenleri (örgütsel bağl11ık, önyargı ve psikolojik yıldırma) ve kontrol değişkenleri (yaş, mesleki kıdem, cinsiyet ve okul büyüklüğü) arasındaki ilişkilere ait korelasyon analizi sonuçları yer almaktadır. 
Tablo 2. Değişkenlere ait Ortalama, Standart Sapma ve Korelasyon Analizi Sonuçları

\begin{tabular}{|c|c|c|c|c|c|c|c|c|c|}
\hline Değişkenler & $\bar{X}$ & SS & 1 & 2 & 3 & 4 & 5 & 6 & 7 \\
\hline 1 Yas & 36.42 & 7.28 & - & & & & & & \\
\hline 2 Mesleki Kıdem & 8,43 & 3,12 & $.93 * *$ & - & & & & & \\
\hline 3 Cinsiyet & - & - & $.06^{*}$ & .04 & - & & & & \\
\hline 4 Okul Büyüklüğü & - & - & .01 & .02 & .07 & - & & & \\
\hline 5 Örgütsel Bağlılık & 4,16 & 0,63 & $.32 *$ & $.38^{*}$ & .06 & $.59 * *$ & - & & \\
\hline 6 Psikolojik Yıldırma & 3,94 & 0,72 & $.42 *$ & $.44^{*}$ & .04 & $.54 * *$ &,$- 76^{* *}$ & - & \\
\hline 7 Önyarg1 & 3,89 & 0,61 & $.61 * *$ & $.60 * *$ & .03 & $.57 * *$ & $-.72 * *$ & $.83 * *$ & - \\
\hline
\end{tabular}

$* * \mathrm{p}<.01 \quad * \mathrm{p}<.05$

Tablo 2'deki sonuçlar incelendiğinde araştırmanın bağımsız değişkeni olan örgütsel bağl1lığın, kontrol değişkenlerinden mesleki kıdem $(r=.38, p<.05)$ ve yaş $(r=.32$, $\mathrm{p}<.05)$ ile pozitif yönlü zayıf ilişkisinin olduğu; buna karşın okul büyüklüğü ( $\mathrm{r}=.59$, $\mathrm{p}<.01)$ ile pozitif yönlü orta düzeyde ilişki içinde olduğu tespit edilmiştir. Benzer şekilde psikolojik yıldırma davranışının, mesleki kıdem $(\mathrm{r}=.44, \mathrm{p}<.05)$ ve yaş $(\mathrm{r}=.42$, $\mathrm{p}<.05)$ ile pozitif yönlü zayıf ilişkisinin olduğu belirlenmiştir. Okul büyüklüğüyle psikolojik yıldırma davranışı arasında pozitif yönlü orta düzeyde bir ilişki söz konusudur $(\mathrm{r}=.54, \mathrm{p}<.01)$. Önyargı davranış1 ile mesleki kıdem $(\mathrm{r}=.60, \mathrm{p}<.01)$, yaş $(\mathrm{r}=.61$, $\mathrm{p}<.01)$ ve okul büyüklüğü $(\mathrm{r}=.57, \mathrm{p}<.01)$ değişkenleri arasında orta düzeyde pozitif yönlü ilişki bulunmaktadır. Psikolojik yıldırma ile önyargı arasında yüksek düzeyde pozitif yönlü ilişki olduğu bulunmuş̧tur ( $\mathrm{r}=$ $.83, \mathrm{p}<.01)$. Örgütsel bağl1lık ise hem psikolojik yıldırma $(r=-.76, p<.01)$ hem de önyargı ile $(r=-.72, p<.01)$ yüksek düzeyde negatif yönlü ilişkiler içerisinde olduğu görülmüştür.

Araştırmanın amacı doğrultusunda örgütsel bağlılık ile psikolojik yıldırma arasındaki ilişkide önyargının aracılık rolünü tespit etmek için Baron ve Kenny'nin (1986) dört aşamalı yaklaşımı doğrultusunda hiyerarşik regresyon analizi uygulanmıştır. Analizin ilk aşamasına kontrol değişkenleri olarak yaş, mesleki kıdem, cinsiyet ve okul büyüklüğü modele girilmiştir. İkinci aşamasında ise örgütsel bağlılı̆̆ın, psikolojik yıldırma üzerindeki etkisinin, önyarg1 aracıllı̆ı ile azalıp azalmadığ 1 veya tamamen kalkıp kalkmadığı tespit edilmiştir. Regrasyon analizine ilişkin sonuçlar Tablo 3'de yer almaktadir. 
Tablo 3. Hiyerarşik Regresyon Analizi Sonuçları

\begin{tabular}{|c|c|c|c|c|c|c|}
\hline \multirow[t]{2}{*}{ Değişkenler } & \multicolumn{2}{|l|}{ Önyargı } & \multicolumn{4}{|c|}{ Örgütsel Bağlılık } \\
\hline & 1.Adım & 2.Adım & 1.Adım & & 2.Adım & \\
\hline \multicolumn{7}{|c|}{ Kontrol Değișkenleri } \\
\hline Yaş & $.36^{* *}$ & $.24 *$ & .20 & .13 & .20 & .29 \\
\hline Mesleki Kıdem & $.37 * *$ & $.20^{*}$ & $.34 * *$ & $.26^{* *}$ & $.34 * *$ & $.36^{* *}$ \\
\hline Cinsiyet & .04 & .02 & .02 & .03 & .02 & .03 \\
\hline Okul Büyüklüğü & $.46^{* *}$ & .41 & .36 & $.25^{*}$ & .36 & $.38^{*}$ \\
\hline \multicolumn{7}{|c|}{ Bağımsız ve Aracı Değișken } \\
\hline Psikolojik Yıldırma & & $.81 * * *$ & & $-.63 * * *$ & & $-.72 * * *$ \\
\hline Önyarg1 & & & & & & $-.79 * * *$ \\
\hline$R^{2}$ & .224 & .558 & .108 & .243 & .108 & .559 \\
\hline$F$ & $6.00 * * *$ & $25.29 * * *$ & $4,64 * *$ & $8.86^{* * *}$ & $4.64 * *$ & $22.65 * * *$ \\
\hline
\end{tabular}

${ }^{* * *} \mathrm{p}<.001 ; * * \mathrm{p}<.01 ;{ }^{*} \mathrm{p}<.05$ Tabloda yer alan değerler standardize edilmiş Beta $(\beta)$ Katsayılarıdır.

Tablo 3'de yer alan sonuçlara göre araştırmanın bağımsız değişkeni olan örgütsel bağlılığın, psikolojik yıldırma davranışı üzerinde ( $\beta=-.63, p<.001)$ negatif yönde etkisi olduğu tespit edilmiştir. Bu doğrultuda araştırmanın birinci hipotezi “Öğretmenlerin örgütsel bağlllık düzeyleri, onlara yönelik psikolojik yıldırma davranışların olumlu yönde etkilemektedir." reddedilmiştir. Aracı değişken önyargının, bağımlı değişken örgütsel bağl1lık üzerinde ise $(\beta=-.79, \mathrm{p}<.001)$ yine negatif yönde etkisi bulunmaktadır. $\mathrm{Bu}$ doğrultuda araştırmanın ikinci hipotezi “ $\ddot{O} \breve{g}$ retmenlerin örgütsel bağlllık düzeyleri, önyargılarını olumlu yönde etkilemektedir" reddedilmiştir. Psikolojik yıldırmanın, aracı değişken önyarg1 üzerinde ise $(\beta=.81$, $\mathrm{p}<.001)$ pozitif yönde etkisi görülmektedir. $\mathrm{Bu}$ sonuç ile araştırmanın üçüncü hipotezi “Öğretmenlere yönelik psikolojik yıldırma davranışları, öğretmenlerin önyargılarını olumlu yönde etkilemektedir." kabul edilmiştir.
Aracı değişken önyargı modele eklendiğinde, psikolojik yıldırmanın, örgütsel bağl11ık üzerindeki etkisinin $\beta=-.63$ 'dan $(p<.001) \beta=-.72(p<.001)$ değerine düştüğü bulunmuştur. Bu sonuç, önyarg1 değişkeninin, psikolojik yıldırmanın örgütsel bağl11ık üzerindeki etkisine tamamen aracılık ettiğini göstermektedir. Daha sonra, aracı değişken olarak önyargının, örgütsel bağl1lığa etkisini anlamlı bir şekilde psikolojik yıldırma üzerine taşıma durumu Sobel (1982) testi ile incelenmiştir. Yapılan test sonucunda aracılık etkisinin anlamlı $(\mathrm{z}=3.39, \mathrm{p}<.01)$ olduğu bulunmuştur. $\mathrm{Bu}$ nedenle dördüncü hipotez “Öğretmenlerin örgütsel bağlllıkları ile onlara yönelik psikolojik yıldırma davranışları arasındaki ilişkide önyargının aracılık etkisi vardır” doğrudan kabul edilmiştir. 


\section{Tartışma, Sonuç ve Öneriler}

$\mathrm{Bu}$ araştırmanın amacı örgütsel bağl11ık ile psikolojik yıldırma arasındaki ilişkide önyargının aracılık rolünü tespit etmektir. Elde edilen bulgular örgütsel bağl1lık davranışının hem önyargı hem de psikolojik yıldırma ile negatif yönde ilişkili olduğunu göstermektedir. Ayrıca önyargı ve psikolojik yıldırma arasındaki ilişkinin de pozitif yönde olduğu görülmüş̧tür. Bu sonuçlar doğrultusunda araştırmanın birinci ve ikinci hipotezi reddedilmiştir. Buna karşın araştırmanın üçüncü hipotezi kabul edilmiştir. Hiyerarşik regresyon analizi sonucu ise örgütsel bağl1lık ve psikolojik yıldırma arasındaki ilişkide önyargının tamamen aracılık ettiği tespit edilmiştir. Diğer bir ifade ile örgütsel bağl1lığa sahip öğretmenler, psikolojik yıldırma davranışlarına karşı önyargılı değillerdir. Önyargıl1 öğretmenler ise okullarda psikolojik yıldırma davranışlarına neden olmaktadır. Bu sonuçlar ile araştırmanın dördüncü hipotezi de kabul edilmiştir.

Alanyazında psikolojik yıldırma ve örgütsel bağlılık arasındaki ilişkiyi açıklamayı amaçlayan araştırmalar, bu araştırmanın söz konusu davranışlar arasındaki ters yönlü ilişkiye yönelik bulgusunu desteklemektedir. Karcıoğlu ve Çelik (2012), banka çalışanları üzerine yaptıkları bir araştırmada psikolojik yıldırma davranışı ile örgütsel bağl1lık arasında ters yönlü bir ilişkinin olduğunu bildirmektedirler. Atalay (2010) ve Yıldız, Akbolat ve Işık (2011), örgütsel bağlılık ve psikolojik yıldırma arasında ters yönlü bir ilişkinin bulunduğu belirlemişlerdir. Özler, Atalay ve Şahin (2008), çalışmalarında psikolojik yıldırmanın yaşandığı örgütlerde; çalışanlarda işten ayrılma niyetinin oluştuğu, örgütsel bağl1lıklarının azaldığı ve buna bağlı olarak çalışan devir hızının arttığı sonucuna ulaşmışlardır. Ancak alanyazındaki farklı araştırmalarda çelişkili sonuçlara da rastlanılmıştır. Tengilimoğlu ve Mansur (2008), psikolojik yıldırma ve örgütsel bağlılık anlamlı bir ilişki bulunmadığını bildirmişlerdir. Kul (2010), psikolojik yıldırma ve örgütsel bağl1lık arasında düşük düzeyli bir ilişki bulunduğunu belirlemiştir. Yüksel ve Tunçsiper (2011), psikolojik yıldırma ile örgütsel bağl1lık arasında pozitif bir ilişki olduğu sonucuna varmışlardır. Örgütsel bağl1lık ve psikolojik yıldırma ilişkisini inceleyen çalışmalar farklı sonuçlar vermekle birlikte genel olarak psikolojik yıldırma davranışlarına maruz kalmanın çalışanların örgüte olan bağl1lıklarını azalttığı söylenebilir.

Alanyazında önyargı ile örgütsel bağl1lık ve psikolojik yıldırma davranışı ilişkisi üzerine yapılan araştırmalarda, önyargı davranışındaki artışın örgütsel bağl1lığ azalttığına ilişkin sonuçlar, bu araştırmanın sonuçlarıyla örtüşmektedir (Greenberg, 2005; Mueller, Finley, Iverson ve Price, 1999; Ashforth, Harrison ve Corley, 2008). Benzer şekilde önyargı davranışı ile psikolojik yıldırma davranışı arasında pozitif yönde ilişkinin bulunduğu sonucuna ulaşan araştırmalarda söz konusudur (Minton, 2014; Sloan, Matyók, Schmitz ve Short, 2010; Sperry ve Duffy, 2009). Önyargının hem 
psikolojik yıldırma ve hem de örgütsel bağlılık davranışları üzerindeki etkisi kabul edilmekle birlikte, alanyazında söz konusu üç davranış arasındaki ilişkileri birlikte açıklamaya yoğunlaşan herhangi bir çalışma bulunmamaktadır.

Araştırma bulgularından hareketle cinsiyetin örgütsel bağl1lık, psikolojik yıldırma ve önyargı davranışları üzerinde etkisinin olmadığ 1 belirlenebilir. Bu sonuç alanyazındaki pek çok bulgu ile benzerlik göstermektedir (Minton, 2014; Tengilimoğlu ve Mansur). Ancak psikolojik yıldırma davranışında mağdurların çoğunlukla kadın olduğunu bulgulayan araştırmalar da söz konusudur (Sperry ve Duffy, 2009). Araştırmada yer alan yaş değişkeni, önyargı ve psikolojik yıldırma davranışları üzerinde etkilidir. Öğretmenlerin yaşları arttıkça daha önyargıl1 olmaktadırlar ve yine daha yaşlı öğretmenler daha fazla psikolojik yıldırma davranışlarına maruz kalmaktadırlar. Bu sonuç alanyazındaki çok sayıda araştırma sonucuyla benzerlikler göstermektedir (Nelson, 2004; Duncan, 2008; Doyle ve Aboud, 1995). Ayrica, mesleki kıdemi fazla olan öğretmenlerin daha fazla örgütsel bağlılığa sahip oldukları görülmektedir. Mesleki deneyim arttıkça öğretmenler daha fazla bağlll1k göstermektedir. Bu sonuç alanyazındaki araştırmalarla benzerlik göstermektedir (Kartal, 2005; Celep, Sarıdede ve Beytekin, 2005).

Araştırmada yer alan okul büyüklüğü değişkeni, okulda çalışan öğretmen sayısını temsil etmektedir. Buna göre okul bü- yüklüğü, örgütsel bağl1lık, psikolojik yıldırma ve önyargı davranışını etkilemektedir. Büyük ölçekli okullarda önyargı ve psikolojik yıldırma davranışları gözlemlenirken, küçük ölçekli okullarda örgütsel bağlllık davranışının daha yüksek olduğu belirlenmiştir. Bunun nedeni olarak, öğretmen sayısı fazla olan okullarda çalışan öğretmenlerin, okuldaki diğer çalışanlarla ilişki kurmakta zorlandığı, daha fazla enformel gruplar içinde yer aldığı ve okulda önyargı davranışının bu tür iletişimsizlikten kaynaklandığı belirlenebilir. Bunun yanında küçük ölçekli okullarda kişilerarası ilişkilerin daha canlı olduğu ve iletişimle birlikte uyum ve özdeşleme ile içselleştirmenin daha fazla gerçekleştirildiği sonucuna varılmıştır.

Örgütlerde görülen önyargının örgütsel bağlılık ve psikolojik yıldırma davranışlarıyla ilişkisini konu edinen bu araştırma, alanyazında kuramsal bahsedilen ancak henüz incelenmeyen önyargının aracı rolüne değinmektedir. Alanyazındaki önemli kuramsal bir varsayımı deneyen bu araştırma yeni çalışma alanlarına ve kuramsal boşlukları belirginleştirmiştir. Önyargı üzerine yapılan diğer çalışmalardan farklı olarak bu araştırma önyargı davranışını bir sonuç değil, diğer davranışların altında yatan önemli bir neden olarak ele almıştır. Özellikle demografik değişkenlerin arttırılarak araştırma sonuçlarının farklı örneklem grupları üzerinde çalışılması, alanyazına önemli katkı sağlayabilir. Ayrıca araştırmanın aracı de- 
ğişkeni moderatör değişken olarak belirlenerek farklı davranışların çalışılması örgütsel davranış alanyazınına katkı sağlayacaktır.

Sosyal bilim araştırmaları, olgusal değişkenlerin dinamik yapısından sıklıkla etkilenmektedirler. Değişken toplumsal sistemlerin en önemli özelliği olan belirsizlik bu araştırma için de geçerlidir. Sosyal bilimlerin değişkenliği ve farklı zamanlarda farklı sonuçların elde edilebileceği gerçeğinden hareketle bu araştırma 2017 yılı içinde Ankara ili merkez ve taşra ilçelerinde çalışan öğretmenlerden toplanan verilerle yapılmıştır. Bu nedenle araştırmanın örneklemi en önemli kısıtll11k olarak görülmektedir. İleride yapılacak araştırmalarda diğer bölgelerin ve sektörlerin tercih edilmesi elde edilen sonuçları daha güçlü hale getirecektir. Bunun yanında önyargı ve diğer davranışların değişken doğası sebebiyle araştırmanın farklı yıllarda tekrarlanması ile zamanın araştırma değişkenlerine olan etkisi incelenmelidir.

\section{Kaynakça}

Allport, G. W., \& Ross, J. M. (1967). Personal religious orientation and prejudice. Journal of personality and social psychology, 5(4), 432.

Allen, N. J., \& Meyer, J. P. (1990). The measurement and antecedents of affective, continuance and normative commitment to the organization. Journal of occupational and organizational psychology, 63(1), 1-18.

Allen, N. J., Meyer, J. P. \& Smith, C. A. (1993). Commitment to organizations and occupations: Extension and test of a three-component conceptualization. Journal of applied psychology, 78(4), 538.

Asamen, J. K., \& Berry, G. L. (1987). Self-concept, alienation, and perceived prejudice: Implications for counseling Asian Americans. Journal of Multicultural Counseling and Development.
Ashforth, B. E., Harrison, S. H., \& Corley, K. G. (2008). Identification in organizations: An examination of four fundamental questions. Journal of management, 34(3), 325-374.

Atalay, İ. (2010). Mobbingin Örgütsel Bağlllık Üzerindeki Etkisi. Кamu Sektöründe Bir Örnek"”, Yüksek Lisans Tezi, Atıllm Üniversitesi Sosyal Bilimler Enstitüsü, Ankara.

Avolio, B. J., Zhu, W., Koh, W., \& Bhatia, P. (2004). Transformational leadership and organizational commitment: Mediating role of psychological empowerment and moderating role of structural distance. Journal of organizational behavior, 25(8), 951-968.

Baltacı, A. (2017). Relations between Prejudice, Cultural Intelligence and Level of Entrepreneurship: A Study of School Principals. International Electronic Journal of Elementary Education, 9(3), 645-666.

Baron, R. M., \& Kenny, D. A. (1986). The moderator-mediator variable distinction in social psychological research: Conceptual, strategic, and statistical considerations. Journal of personality and social psychology, 51(6), 1173.

Biswas, S., \& Bhatnagar, J. (2013). Mediator analysis of employee engagement: role of perceived organizational support, PO fit, organizational commitment and job satisfaction. $\mathrm{Vi}$ kalpa, 38(1), 27-40.

Blumer, H. (1958). Race prejudice as a sense of group position. Pacific Sociological Review, 1(1), 3-7.

Branch, S., Ramsay, S., \& Barker, M. (2013). Workplace bullying, mobbing and general harassment: A review. International Journal of Management Reviews, 15(3), 280-299.

Buchanan, B. (1974). Building organizational commitment: The socialization of managers in work organizations. Administrative science quarterly, 533-546.

Castro, M. C. (2010). Forms of ethnic prejudice: Assessing the dimensionality of a Spanishlanguage version of the Blatant and Subtle Prejudice Scale. Psicothema, 22(1), 118-124.

Celep, C. Saridede. U., ve Beytekin, F. (2005). Eğitim Örgütlerinde Örgütsel Bağlllık, Örgütsel Vatandaşlık Davranışı Ve Tükenmişlik Arasındaki İlişki, XIV. Ulusal Eğitim Bilimleri Kongresi Pamukkale Üniversitesi, Egitim Fakültesi, 13-19, Denizli.

Cemaloğlu, N. (2007). Örgütlerin kaçınılmaz sorunu: Y1ldirma. Bilig, 42, 111-126. 
Chun, J. S., Shin, Y., Choi, J. N., \& Kim, M. S. (2013). How does corporate ethics contribute to firm financial performance? The mediating role of collective organizational commitment and organizational citizenship behavior. Journal of Management, 39(4), 853-877.

Cochran, W. G. (2007). Sampling techniques. New York: John Wiley \& Sons.

Cook, J., \& Wall, T. (1980). New work attitude measures of trust, organizational commitment and personal need non-fulfilment. Journal of occupational psychology, 53(1), 39-52.

Cortina, J. M. (1993). What is coefficient alpha? An examination of theory and applications. Journal of applied psychology, 78(1), 98.

Crawshaw, L. (2009). Workplace bullying? Mobbing? Harassment? Distraction by a thousand definitions. Consulting Psychology Journal: Practice and Research, 61(3), 263.

Curio, E., Ernst, U., \& Vieth, W. (1978). Cultural transmission of enemy recognition: one function of mobbing. Science, 202(4370), 899901.

Devine, P. G. (1989). Stereotypes and prejudice: Their automatic and controlled components. $\mathrm{JO}_{\mathrm{O}}$ urnal of personality and social psychology, 56(1), 5 .

Dhar, R. L. (2015). Service quality and the training of employees: The mediating role of organizational commitment. Tourism Management, 46, 419-430.

DiPaola, M., \& Tschannen-Moran, M. (2014). Organizational citizenship behavior in schools and its relationship to school climate. Journal of School Leadership, 11(5), 424-447.

Dovidio, J. F., \& Gaertner, S. L. (1986). Prejudice, discrimination, and racism: Historical trends and contemporary approaches. Academic Press.

Dovidio, J. F., Glick, P. E., \& Rudman, L. A. (2005). On the nature of prejudice: Fifty years after Allport. Blackwell Publishing.

Doyle, A. B., \& Aboud, F. E. (1995). A longitudinal study of White children's racial prejudice as a social-cognitive development. Merrill-Palmer Quarterly (1982-), 209-228.

Duckitt, J. H. (1992). The social psychology of prejudice. Praeger Publishers/Greenwood Publishing Group.

Duffy, M., \& Sperry, L. (2007). Workplace mobbing: Individual and family health consequences. The Family Journal, 15(4), 398-404.
Duncan, C. (2008). The dangers and limitations of equality agendas as means for tackling old-age prejudice. Ageing and society, 28(08), 11331158.

Eagly, A. H., \& Karau, S. J. (2002). Role congruity theory of prejudice toward female leaders. Psychological review, 109(3), 573.

Einarsen, S. (1999). The nature and causes of bullying at work. International journal of manpower, 20(1/2), 16-27.

Einarsen, S., \& Raknes, B. I. (1997). Harassment in the workplace and the victimization of men. Violence and victims, 12(3), 247-263.

Erdemir, S., \& Murat, M. (2014). İlköğretim Öğretmenlerinin Duygusal Zeka Düzeyleri ile Yaşadıkları Psikolojik Yıldırma Arasındaki İlişkinin İncelenmesi. Mustafa Kemal Üniversitesi Sosyal Bilimler Enstitüsü Dergisi, 11(25).

Fiske, S. T. (2000). Stereotyping, prejudice, and discrimination at the seam between the centuries: Evolution, culture, mind, and brain. European Journal of Social Psychology, 30(3), 299-322.

Green, A. E., Dishop, C. R., \& Aarons, G. A. (2016). Organizational Stress as Moderator of Relationship Between Mental Health Provider Adaptability and Organizational Commitment. Psychiatric Services, 67(10), 1103-1108.

Greenberg, J. (2005). Managing behavior in organizations. Prentice Hall.

Hofman, P. S., \& Newman, A. (2014). The impact of perceived corporate social responsibility on organizational commitment and the moderating role of collectivism and masculinity: evidence from China. The International Journal of Human Resource Management, 25(5), 631-652.

Hubert, A. B., \& Van Veldhoven, M. (2001). Risk sectors for undesirable behaviour and mobbing. European journal of work and organizational psychology, 10(4), 415-424.

Karcıŏ̆lu, F., \& Çelik, Ü. H. (2012). Mobbing (yıldırma) ve örgütsel bağlılığa etkisi. Atatürk Üniversitesi İktisadi ve İdari Bilimler Dergisi, 26(1).

Kartal, S. (2005). İlköğretim okulu yönetici ve öğretmenlerinin örgütsel sosyalleşmesi, Ege Ĕgitim Dergisi, 6, 99 - 112

Keim, J., \& McDermott, J. C. (2010). Mobbing: Workplace violence in the academy. In The Educational Forum (Vol. 74, No. 2, pp. 167173). Taylor \& Francis Group.

Kinder, D. R., \& Sears, D. O. (1981). Prejudice and politics: Symbolic racism versus racial threats to the good life. Journal of personality and social psychology, 40(3), 414 
Kul, M. (2010), “Okul Yöneticilerinin Liderlik Stilleri İle Beden Eğitimi Öğretmenlerinin Yıldırma (Mobbing) Yaşama Düzeyleri, Örgütsel Bağlılıkları ve İş Doyumu Arasındaki İlişski”, $Y a$ yınlanmamış Doktora Tezi, Gazi Üniversitesi Ĕ̆itim Bilimleri Enstitüsü, Ankara

Küçükçayır, G. A., \& Altun, S. A. (2016). Eğitim Örgütlerinde Etnik-Kültürel Yıldırma ve Yaşantıları Üzerine Bir Durum Çalışması. Kuram ve Uygulamada Egitim Yönetimi Dergisi, 22(2), 137-164.

Lewis, D. (1999). Workplace bullying-interim findings of a study in further and higher education in Wales. International Journal of Manpower, 20(1/2), 106-119.

Leymann, H. (1990). Mobbing and psychological terror at workplaces. Violence and victims, 5(2), 119-126.

Leymann, H. (1996). The content and development of mobbing at work. European journal of work and organizational psychology, 5(2), 165184.

Leymann, H., \& Gustafsson, A. (1996). Mobbing at work and the development of post-traumatic stress disorders. European Journal of work and organizational psychology, 5(2), 251-275.

Lutgen-Sandvik, P. (2008). Intensive remedial identity work: Responses to workplace bullying trauma and stigmatization. Organization, 15(1), 97-119.

Martin, B., \& Peña, F. (2012). Mobbing and suppression: Footprints of their relationships. Social Medicine, 6(4), 217-226.

Masson, C. N., \& Verkuyten, M. (1993). Prejudice, ethnic identity, contact and ethnic group preferences among Dutch young adolescents. Journal of Applied Social Psychology, 23(2), 156168.

Meyer, J. P., \& Allen, N. J. (1991). A threecomponent conceptualization of organizational commitment. Human resource management review, 1(1), 61-89.

Meyer, J. P. (2015). Organizational commitment. Wiley Encyclopedia of Management.

Meyer, I. H. (2003). Prejudice, social stress, and mental health in lesbian, gay, and bisexual populations: conceptual issues and research evidence. Psychological bulletin, 129(5), 674.

Minton, S. J. (2014). Prejudice and effective anti-bullying intervention: Evidence from the bullying of "minorities". Nordic Psychology, 66(2), 108-120.
Mueller, C. W., Finley, A., Iverson, R. D., \& Price, J. L. (1999). The effects of group racial composition on job satisfaction, organizational commitment, and career commitment the case of teachers. Work and Occupations, 26(2), 187219.

Nelson, T. D. (2004). Ageism: Stereotyping and prejudice against older persons. MIT press.

Neuman, L. W. (2014). Social research methods. New York: Pearson Education Limited.

Niedl, K. (1996). Mobbing and well-being: Economic and personnel development implications. European journal of work and organizational psychology, 5(2), 239-249.

O'Reilly, C. A., \& Chatman, J. (1986). Organizational commitment and psychological attachment: The effects of compliance, identification, and internalization on prosocial behavior. Journal of applied psychology, 71(3), 492.

Özgan, H , Kara, M , Arslan, M . (2013). Öğretmenlerin okul yöneticilerine uyguladıkları psikolojik yıldırma uygulamaları ve etkileri. $E$ AJELI Anatolian Journal of Educational Leadership and Instruction, 1(1), 2-14. Retrieved from http://dergipark.gov.tr/ajeli/issue/1520/18701

Özler, D. E., Atalay, C. G., \& Şahin, M. D. (2008). Mobbing'in örgütsel bağlılık üzerine etkisini belirlemeye yönelik bir araştırma. Dumlupinar Üniversitesi Sosyal Bilimler Dergisi, 22, 37-60.

Pelit, E., \& Kılıç, İ. (2012). Mobbing ile örgütsel bağlılık ilişkisi: şehir ve sayfiye otellerinde bir uygulama. Iş̧letme Araştırmaları Dergisi,4(2), 122-140.

Pettigrew, T. F., \& Meertens, R. W. (1995). Subtle and blatant prejudice in Western Europe. European journal of social psychology, 25(1), 57-75.

Ping, R. A. (2015). Taking Another Look at Organizational Commitment. In New Meanings for Marketing in a New Millennium (pp. 202-202). Springer International Publishing.

Porter, L. W., Steers, R. M., Mowday, R. T., \& Boulian, P. V. (1974). Organizational commitment, job satisfaction, and turnover among psychiatric technicians. Journal of applied psychology, 59(5), 603.

Porter, L. W., Mowday, R. T. \& Steers, R. M., (1979). The measurement of organizational commitment. Journal of vocational behavior, 14(2), 224-247. 
Ponterotto, J. G., \& Pedersen, P. B. (1993). Preventing prejudice: A guide for counselors and educators. Sage Publications, Inc.

Reichers, A. E. (1985). A review and reconceptualization of organizational commitment. Academy of management review, 10(3), 465-476.

Rivers, I., \& Smith, P. K. (1994). Types of bullying behaviour and their correlates. Aggressive behavior, 20(5), 359-368.

Salin, D. (2003). Bullying and organisational politics in competitive and rapidly changing work environments. International Journal of Management and Decision Making, 4(1), 35-46.

Sijtsma, K. (2009). On the use, the misuse, and the very limited usefulness of Cronbach's alpha. Psychometrika, 74(1), 107.

Sloan, L. M., Matyók, T., Schmitz, C. L., \& Short, G. F. L. (2010). A story to tell: Bullying and mobbing in the workplace. International Journal of Business and Social Science, 1(3).

Sobel, M. E. (1982). Asymptotic confidence intervals for indirect effects in structural equation models. Sociological methodology, 13, 290-312.

Sperry, L., \& Duffy, M. (2009). Workplace mobbing: Family dynamics and therapeutic considerations. The American Journal of Family Therapy, 37(5), 433-442.

Stevens, J. M., Beyer, J. M., \& Trice, H. M. (1978). Assessing personal, role, and organizational predictors of managerial commitment. Academy of management journal, 21(3), 380-396.

Şeker, S.D. (2011), Türkiye'nin İnsani Gelișme Endeksi ve Endeks Siralamasinın Analizi, DPTSSKGM: Ankara.

Sener, O. (2013). Genel kamu liselerinde psikolojik yıldırma ve örgütsel bağlılık ilişkisi. Çankırl Karatekin Üniversitesi Karatekin Edebiyat Fakültesi Dergisi, 1(1), 47.
Tajfel, H. (1969). Cognitive aspects of prejudice. Journal of social issues, 25(4), 79-97.

Tengilimoğlu, D. ve F. Akdemir Mansur (2008), "İşletmelerde Uygulanan Mobbingin (Psikolojik Şiddet) Örgütsel Bağlılığa Etkisi”, 7. Ulusal Büro Yönetimi ve Sekreterlik Kongresi, 22-24 Ekim 2008, 199-213.

Tett, R. P., \& Meyer, J. P. (1993). Job satisfaction, organizational commitment, turnover intention, and turnover: path analyses based on metaanalytic findings. Personnel psychology, 46(2), 259-293.

Van Dijk, T. A. (1987). Communicating racism: Ethnic prejudice in thought and talk. Sage Publications, Inc.

Vartia, M. (1996). The sources of bullyingpsychological work environment and organizational climate. European journal of work and organizational psychology, 5(2), 203-214.

Wood, V. R., \& Wilberger, J. S. (2015). Globalization, Cultural Diversity and Organizational Commitment: Theoretical Underpinnings. World, 6(2), 154-171.

Yıldız, G., Akbolat, M. ve O. Ișık (2011), "Psikolojik Taciz ve Örgütsel Bağlılık: Sağlık Çalışanları Üzerine Bir Araştırma”, Kırgızistan Türkiye Manas Üniversitesi Sosyal Bilimler Dergisi, 25, 113-141.

Yüksel, M ve B. Tunçsiper, (2011), “The Relationship Between Mobbing and Organizational Commitment in Workplace", International Review of Management and Marketing, 1(3), 54-64.

Zapf, D. (1999). Organisational, work group related and personal causes of mobbing/bullying at work. International journal of manpower, 20(1/2), 70-85. 